\title{
Low Cost Maize Planting Unit for Conventional Plough
}

\author{
K.L. Dabhi*, R.C. Salunkhe and R.S. Godhani \\ Department of Farm Machinery and Power Engineering, College of Agricultural Engineering \\ and Technology, Anand Agricultural University, Godhra, Gujarat, India \\ *Corresponding author
}

\begin{tabular}{|l|}
\hline Ke y w o r d s \\
Maize planting unit, \\
$\begin{array}{l}\text { Dibbling method, } \\
\text { Conventional plough, } \\
\text { Field efficiency }\end{array}$ \\
\hline Article Info \\
\hline $\begin{array}{l}\text { Accepted: } \\
\text { 07 April } 2018 \\
\text { Available Online: } \\
\text { 10 May } 2018\end{array}$ \\
\hline
\end{tabular}

\section{Introduction}

In India, the agricultural lands are decreasing as population increases. In other word, the land holdings of farmers are decreasing day by

\section{A B S T R A C T}

Maize crop is an important food crop of the world. To fulfill the requirement of maize over increasing population researchers have to develop and promote technologies which can meet the requirement with reduced cost of cultivation. Sowing of maize is being carried out by different methods all over the world depending upon the soil and availability of sowing implements. Delay in sowing because of shortage of labour during season causes progressive decrease in yield. The area under maize crop may increase if sowing is mechanized. The availability of labours for different farm operations is a serious issue for farmers. The mechanization in various farm operations will help the farmers to get relief from labour requirement. The use of planter for various crops will improve the quality of planting in addition to removal of human drudgery during planting. As maize is the main food crop of the region, a planting unit is so designed as it can be easily attached to the conventional wooden plough and also cheap enough so that poor farmers can purchase and use it. To get desired results by this practice, an inclined plate type seed metering mechanism for the maize planting unit was developed and the unit was tested in the laboratory and its performance for maize sowing was compared with dropping seeds into funnel type seeding device connected to plough and dibbling method. The evaluation results found that the unit gives the nearly recommended seed rate $(22.26 \mathrm{~kg} / \mathrm{ha})$ with negligible damage of seeds. It also obtained uniform seed to seed spacing $(19.84 \mathrm{~cm})$ in the field. The field capacity of the planter was found to be $(0.1086 \mathrm{ha} / \mathrm{h})$ which was higher than dropping seeds into funnel type seeding device connected to plough $(0.0674 \mathrm{ha} / \mathrm{hr})$ and dibbling method $(0.007926 \mathrm{ha} / \mathrm{hr})$. The field efficiency of the planting unit was found (77.90\%) which was the highest followed by $73.51 \%$ and $67.08 \%$ in case of dropping seeds into funnel type seeding device connected to plough and dibbling method, respectively. The cost of planting with the developed planting unit per ha was obtained $₹$ 920 whereas it was estimated in another dropping seeds into funnel type seeding device connected to plough and dibbling method is $₹ 2314$ and $₹ 3158$, respectively.

day. In middle Gujarat the majority of farmers are small and marginal so that they cannot afford fully mechanized farming due to their economical condition and field sizes, too. The main food crop of the region is maize and 
farmers are still using a bullock pair to perform various field operations. Maize or corn is one of the most important cereal crops in the world's agricultural economy both as food for man and feed for animals including poultry. It is also known as "queen of cereals" because of very high yield potential. Over $85 \%$ of maize produced in the country is consumed as human food. Green cobs are roasted and consumed by people with great interest. It is also a good food for poultry, piggery and other animals.

In future due to increasing population, demand of maize will be increased. Since the area under maize is almost stagnating and there is little scope of horizontal expansion, the projected maize demand will have to produce by increasing productivity. At the same time, in the present era of globalization, it is of immense importance to reduce the cost of maize production and to make it competitive in international market. Researchers have to develop and promote technologies which can meet the challenge of increasing food production to match population growth with reduced cost of cultivation.

In India, maize is traditionally grown in monsoon (Kharif) season, which is accompanied by high temperature $\left(>35^{\circ} \mathrm{C}\right)$ and rains. However, with the development of new cultivars and appropriate production technology, winter cultivation of maize has emerged as a viable alternative. Since about $85 \%$ of maize in India is grown during monsoon season, where over $80 \%$ of the total annual precipitation is received, it thus is very imperative for the soil to have adequate water holding capacity as also the proper drainage to minimize damage due to water logging and seed and seedling diseases.

The farmers of this region are using various methods for sowing of maize, depending upon available resources with them, viz. sowing with dibbler, bullock drawn country plough, tractor drawn maize planter, tractor drawn seed cum fertilizer drill etc. Kumar (1984) designed and fabricated a manually operated single row planter using different seed plates having differences in size of cells. The seed plates were divided into two halves so that they could easily be replaced. This planter was tested for maize, pea, and arhar seeds. MandaI and Ojha (1986) developed a manually operated four rows seed drill. Separate wooden discs were used for metering different size or number of drilling for different seeds. Ayub et al., (1998) suggested that the line sowing of maize significantly increases the maize yield as well as fodder. Bamgboye and Mofolasayo (2006) developed a manually operated two-row Okra planter. The field efficiency and field capacity were $71.75 \%$ and $0.36 \mathrm{ha} / \mathrm{hr}$ while seed rate was $0.36 \mathrm{~kg} / \mathrm{hr}$ with low average seed damage of $3.51 \%$. The row to row and plant to plant spacing for maize is recommended as $60 \mathrm{~cm} \times 20 \mathrm{~cm}$. During the process of sowing one and half to two times seed is being utilized by farmers than actual recommended doze (20-25 kg/ha) which results in higher plant population and necessitates thinning operation and ultimately increases cost of production. Under such circumstances both quality and quantity of yield goes deteriorated.

A poor sowing method will result in poor harvesting of crop and less yield. Important factors that affect germination and emergence of plant include:

Quality of seed to be planted.

Type of soil.

Uniformity of seed distribution.

Type of furrow openers.

Type of covering device.

Type of metering mechanism.

Distance between row to row etc.

Modern farming calls for carful sowing to get the highest yield. The sowing operation involves opening the furrow to the proper 
depth, meter the seed, placing the seed in the furrow in an acceptable pattern and covering the seed and compacting the soil around the seed to proper.

However, the selection of any type of sowing equipment depends upon its ability to place the seed at proper distance and depth without clusters with minimum draft and better coverage degree.

About 70 to $80 \%$ of total cropped area of Panchmahals region is covered under maize crop. Generally, the dibbling method and a person walks behind a bullock drawn conventional plough by dropping the seeds alone or a mixture of seeds and fertilizer into the furrow opened by the plough are very popular among small and marginal farmers of this region, which are;

Very labour intensive

Tedious

Costly

Improper seed placement

Excessive seed rate

Now a days, there is scarcity to find labours in required numbers and at operation desired price. Even if one gets it, then there is no guaranty to timeliness in and proper plant to plant distance. So, a research project was carried out at CAET, Anand Agricultural University, Godhra, Gujarat with following objectives:

To design a low cost single row maize planting unit.

Performance evaluation of the maize planting in the laboratory as well as in the field.

Comparison of the performance of maize planting unit with two local methods of maize sowing.
To find out the cost of maize sowing operation of the three sowing methods under study.

\section{Materials and Methods}

A design of low cost maize planting unit for conventional plough with bevel gear assembly was prepared and the same was developed in the workshop of the college which consists of following components.

Seed hopper

Seed metering mechanism

Transmission system

Drive wheel

Seed tube

Conventional plough (For making furrow)

The various components of developed low cost maize planting unit for conventional plough are as follows:

\section{Seed hopper}

It is a hopper made by galvenize iron. Seed metering mechanism is placed at the rear side of this hopper. Seed hopper is trapezoidal in shape with 5 to $6 \mathrm{~kg}$ of capacity.

\section{Seed metering mechanism}

The mechanism which picks up seeds from the seed hopper and delivers them into the seed tube. A shutter is provided for regulating the flow of seeds from the hopper to this mechanism.

Inclined plate type wooden seed metering device was used to get the recommended seed rate.

\section{Transmission system}

The transmission mechanism consists of a wheel, a drive shaft and a driven shaft that carry the seed metering device. Bevel gears of 
equal teeth were used to convert the forward motion of the wheel at right angles to rotate the inclined plate type metering device

\section{Drive wheel}

One peg type drive wheel is fitted with two bevel gear assembly to facilitate the metering of seeds. The diameter of wheel is $47 \mathrm{~cm}$ and 12 pegs are provided to transmit the motion of the wheel to the seed metering mechanism when the low cost planting unit for conventional plough makes forward motion in the field.

\section{Seed tube}

The seed tube is made from transparent PVC pipe. It is fitted at the bottom of the seed metering box and extended downward behind the country plough in such a way that it drops the seeds into the furrows opened by the conventional plough.

\section{Conventional plough (Wooden plough to make the furrow for seed dropping)}

This is a conventional plough which is widely used by the farmers for seed bed preparation, inter culturing, making furrows to provide irrigation facility for row crops like cotton, castor, vegetables etc. The locally used plough is selected to connect the low cost maize planting unit for conventional plough to save an extra labour, to save the time of sowing operation as compared to dibbling method, to reduce the seed rate by maintaining the predetermined seed rate and to maintain recommended and uniform plant population in the field.

\section{Laboratory test}

The planting unit has been tested in laboratory condition as well as in field conditions. The following tests were conducted in laboratory at Farm Machinery and Power Engineering Department, College of Agricultural Technology, Anand Agricultural University, Godhra.

\section{Soil moisture content}

Moisture content for soil is computed on dry basis. Soil sample were collected from 0 to 20 $\mathrm{cm}$ depth of soil surface before operation for determination of moisture content \& bulk density. The moisture content (dry basis) was determined by the following formula

Moisture content $(\%)=\frac{w_{\mathrm{w}}-w_{\mathrm{d}}}{\mathbf{w}_{\mathrm{d}}} \times \mathbf{1 0 0}$

Where,

$\mathrm{Ww}=$ Weight of wet soil sample, and $\mathrm{Wd}=$ Weight of dry soil sample

\section{Bulk density}

The bulk density is the weight of soil to its volume. The samples were taken from 0 to 20 $\mathrm{cm}$ depth of soil surface in a $100 \mathrm{cc}$ capacity core sampler and its weight was determined in electronic balance and the bulk density was determined in the laboratory by oven dry method as per following formula.

$\begin{aligned} & \text { Bulk density } \\ & \frac{\text { Weight of dry soil sample (gm) }}{\text { Volume of core sample (cc) }}\end{aligned} \quad=$

\section{Calibration test for the planting unit}

Calibration of the unit was done by standard method in the laboratory to determine the seed rate which may be obtained during field testing.

\section{Mechanical seed damage test}

The test was conducted to find out percentage of damage of seeds during actual operation. 
The percentage of damage seeds during calibration was found out by rotating the ground wheel for 20 revolutions. The amounts of seeds collected were counted and out of this, the total numbers of damaged seeds were counted separately and mechanical damage percentage was calculated as follows.

Mechanical

percentage $=\frac{\text { Number of damaged seed }}{\text { Total number of seeds collected }}$

damage

The test was replicated for 5 times and the average damaged percentage was worked out.

\section{Field test}

The planting unit was evaluated in the field as peer RNAM test codes. Under field testing of the developed planting unit, seed uniformity test, number of missing, number of doubles, travel reduction, effective field capacity, field efficiency and cost of operation were determined. At same time, the effective field capacity and cost of operation of two local maize sowing methods were worked out.

\section{Experimental technique}

Three different sowing methods of maize were used for comparison as under (Figure 1).

Sowing the seeds by attaching the developed maize planting unit to conventional plough

Dropping seeds into funnel type seeding device connected to plough and

Dibbling method.

\section{Seed uniformity test}

Prepared a leveled bed of $25 \mathrm{~m}$ x $5 \mathrm{~m}$ the field. Allowed the planting unit to travel over these beds and observed the number of seeds dropped and the average distance between two seeds for each 5 meter of bed length.

\section{Number of missing}

The planting unit was operated in the field and the distances between two consecutive seeds were measured in a span of $5 \mathrm{~m}$, if the distance between two seed exceeded 1.5 times of the theoretical or recommended spacing, then this was considered as missing observation.

\section{Number of doubles}

If the distance between two seed was found less than $10 \mathrm{~cm}$ at the time of measuring distance between two seeds then this was considered as number of doubles. Even if a cluster of three to four seeds was found it was taken as doubles.

\section{Travel reduction (wheel slip)}

A mark was made on the drive wheel with colored tapes and the distance of the plan ting unit moved forward at every 10 revolution in the field and the same distance theoretically can it cover in 10 revolution will be determined and the it was found out as follows:

T.R. $($ wheel slip $)=\frac{\mathrm{M} 2-\mathrm{M} 1}{\mathrm{M} 2} \times 100$

Where,

T.R. $=$ Travel Reduction $(\%)$

M2 = Distance covered at every 10 revolution of drive wheel in the field (m)

M1 = Distance covered at every 10 revolution by the drive wheel in the lab (m)

\section{Field efficiency}

The theoretical field capacity is the rate of field coverage that would be obtained if the planting unit was operating continuously 
without interruption like turning at the end and filling of hopper. The effective field capacity is the actual average rate of coverage including the time lost in filling the hopper and turning at the end of the rows. Theoretical field capacity, effective field capacity and field efficiency were computed by using the following formula:

Theoretical field capacity $(\mathrm{ha} / \mathrm{h})=\frac{\mathbf{w \times s}}{10}$

Where,

$\mathrm{W}=$ Width of planting unit for one strip (m)

$\mathrm{S}=$ Speed of operation, $\mathrm{km} / \mathrm{h}$.

Effective field capacity $(\mathrm{ha} / \mathrm{h})=\frac{\text { Area of plot (ha) }}{\text { Time taken (h) }}$

Field efficiency is the ratio of the effective field capacity to the theoretical field capacity as shown as below:

F.E. $=\frac{\text { EFC }}{\text { TEC }} \times 100$

Where,

F.E. $=$ Field efficiency percent

$\mathrm{EFC}=$ Effective field capacity, ha/h

$\mathrm{TFC}=$ Theoretical field capacity, ha/h

\section{Cost of operation}

The costs of operation in each method were determined in term of rupees per hectare and comparison among three was made.

\section{Results and Discussion}

\section{Laboratory results}

\section{Soil moisture content and bulk density}

The results revealed that the average moisture content recorded at $0-20 \mathrm{~cm}$ depth was $15.89 \%$ and bulk density at same depth was $1.32 \mathrm{~g} / \mathrm{cc}$.

\section{Calibration of planting unit in laboratory}

During the calibration of the unit, average seed rate obtained was $22.78 \mathrm{~kg} / \mathrm{ha}$

\section{Mechanical damage test}

The total seed damage was obtained $0.54 \%$ which was very negligible.

\section{Field test}

The layout before field operation was prepared for three maize sowing methods.

\section{Seed uniformity test}

The maize planting unit was calibrated at College Instructional farm by operating for 5 $\mathrm{m}$ run to determine the actual seed to seed distance in the field. The observations obtained were recorded in table 1 .

No. of missing and no. of doubles and triples for planting unit

The average number of missing (for 5 meter length) was found at 2 places and the average no. of doubles \& triples (for 5 meter length) was found at 2 places and 1 places, respectively.

Travel reduction (wheel slip) in case of planting unit

The wheel slip for the planting unit was recorded as 6.92 percent.

\section{Average spacing after germination of maize crop}

After germination at $15 \mathrm{DAS}$, the average seed to seed spacing was recorded $19.84 \mathrm{~cm}$ in case of sowing by developed low cost maize planting unit. 
Table.1 Uniformity test for planting unit

\begin{tabular}{l} 
Parameter \\
\hline Observation No. \\
\hline No. of seeds fallen \\
Average distance between two seeds \\
(cm)
\end{tabular}

\begin{tabular}{|c|c|c|c|c|c|}
\hline \multicolumn{5}{|c|}{ Bed length 5m } & A verage \\
\hline 1 & 2 & 3 & 4 & 5 & \\
\hline 26 & 25 & 27 & 23 & 25 & 25.2 \\
\hline 19.23 & 20.00 & 18.51 & 21.73 & 20.00 & 19.84 \\
\hline
\end{tabular}

Table.2 Determination of theoretical field capacity, effective field capacity and field efficiency for three methods

\begin{tabular}{|c|l|c|c|c|}
\hline Sr. No. & \multicolumn{1}{|c|}{ Sowing method } & $\begin{array}{c}\text { Theoretical field } \\
\text { capacity (ha/h) }\end{array}$ & $\begin{array}{c}\text { Effective field } \\
\text { capacity (ha/h) }\end{array}$ & $\begin{array}{c}\text { Field } \\
\text { efficiency }(\%)\end{array}$ \\
\hline 1 & $\begin{array}{l}\text { Planting by developed low } \\
\text { cost maize planting unit }\end{array}$ & 0.1394 & 0.10860 & 77.90 \\
\hline 2 & $\begin{array}{l}\text { Dropping seeds into funnel } \\
\text { type seeding device } \\
\text { connected to plough. }\end{array}$ & 0.0918 & 0.06749 & 73.51 \\
\hline 3 & Dibbling method & 0.0118 & 0.007916 & 67.08 \\
\hline
\end{tabular}

Table.3 Time required and cost of sowing operations

\begin{tabular}{|l|c|c|}
\multicolumn{1}{|c|}{$\begin{array}{c}\text { Sowing method } \\
\text { Planting by developed low cost maize }\end{array}$} & $\begin{array}{c}\text { Time required for sowing } \\
\text { 1 ha area (hour/ha) }\end{array}$ & $\begin{array}{c}\text { Cost of } \\
\text { operation (Rs/ha) }\end{array}$ \\
\hline $\begin{array}{l}\text { planting unit } \\
\text { Dropping seeds into funnel type seeding } \\
\text { device connected to plough }\end{array}$ & 9.36 & 920 \\
\hline Dibbling method & 14.81 & 1851 \\
\hline
\end{tabular}

Conventional plough (Wooden plough to make the furrow for seed dropping)
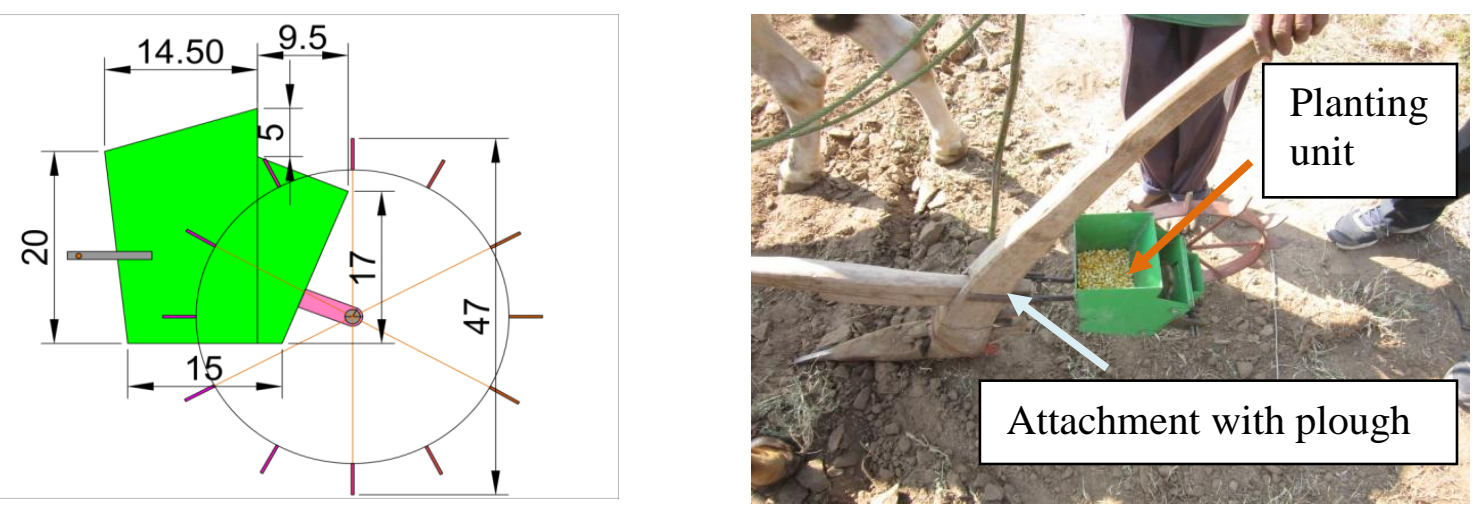

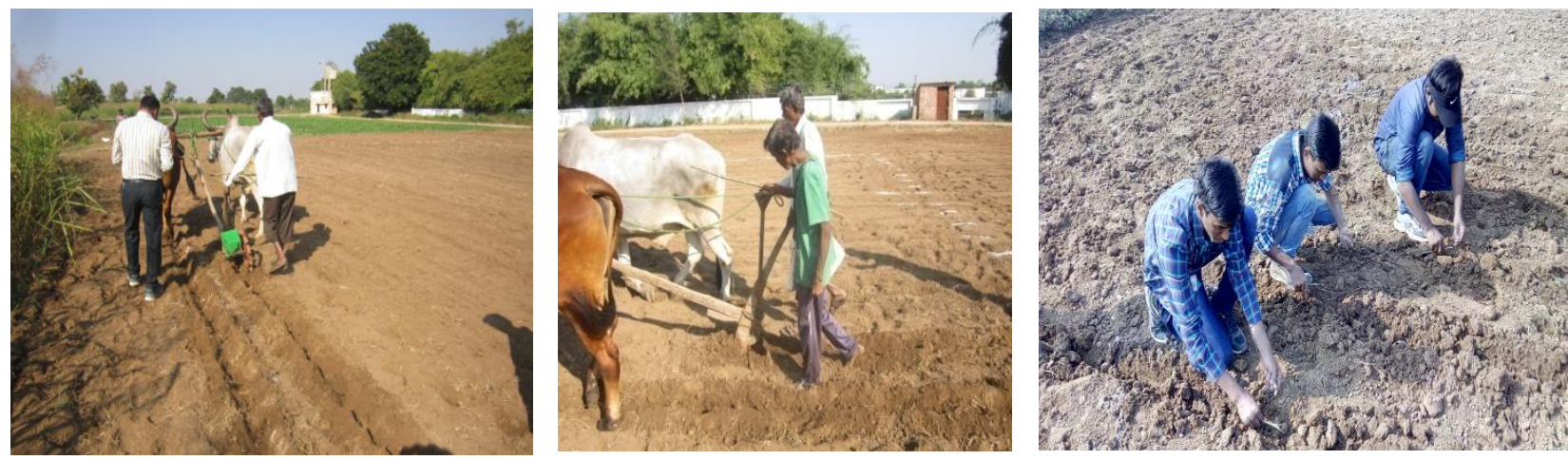

Fig.1 Three different sowing methods of maize in the field

As per the results shown in table 2, the effective field capacity i.e. $0.1086 \mathrm{ha} / \mathrm{h}$ was highest in case of maize sowing by developed low cost maize planting unit among three sowing methods under the study. Maize sowing by developed low cost maize planting unit saves $37.87 \%$ and $92.71 \%$ time as compared to sowing by dropping seeds into funnel type seeding device connected to plough and by dibbling method, respectively (Table 3). Maize sowing by developed low cost maize planting unit saves $50.30 \%$ and $70.86 \%$ cost of sowing operation as compared to sowing by dropping seeds into funnel type seeding device connected to plough and by dibbling method, respectively (Table 3). The average spacing after germination in case of planting with developed low cost maize planting unit was obtained as $19.84 \mathrm{~cm}$ which is very close to the recommended spacing of maize crop.

\section{References}

Ayub et al., (1998). Fodder yield and quality of four cultivars of maize (Zea mays L) under different methods of sowing. Pakistan Journal of Biological Sciences, 30(1): 17-19

Bamgboye, A.I. and Mofolasayo, A.S. (2006). Performance Evaluation of a two-row okra Planter. Agricultural Engineering International: the CIGR Ejournal. Manuscript PM. 06 002, Vol. VIII.

http://epubs.icar.org.in/ejournal/index.php/JA E/index

http://www.indianjournals.com

Kumar, A. (1984). Design and fabrication of manually operated single row planter, M.Sc. (Agril. Engg.) Thesis, Allahabad Agricultural Institute, Allahabad, U.P. (India).

Mandal, T.C. and Ojha, T.P. (1986). Manually operated four row seed drill for small seeds. Agric. Engg. Today, 10 (4): 4-6.

Sanjay Kumar Nirala (2011). Performance evaluation of bullock drawn multi crop inclined plate planter. International Journal of Agric. Engg., 4 (2): 193-199.

\section{How to cite this article:}

Dabhi, K.L., R.C. Salunkhe and Godhani, R.S. 2018. Low Cost Maize Planting Unit for Conventional Plough. Int.J.Curr.Microbiol.App.Sci. 7(05): 715-722. doi: https://doi.org/10.20546/ijcmas.2018.705.086 